\title{
Developing Edugames Learning Media Based on Local Culture
}

\author{
Henny Suharyati ${ }^{1)}$,Griet Helena ${ }^{2)}$ \\ Management of Education Program, Pakuan University, Bogor, Indonesia ${ }^{1) \& 2)}$ \\ henny.suharyati@unpak.ac.id
}

\section{Keywords :}

Edugames learning media, Local culture, Character development

\begin{abstract}
Technology has become the consumption of the wider community, one of which is the entertainment needs for games. Many games are on the market but the substance is not feasible for children's consumption as well as the figures shown are derived from foreign cultures with themes emerging about violence and sadism. In order to anticipate the above situation, a study was developed to produce educational games learning media based on local culture. This research will produce educational games products that can be specially played by children aged 7 years and over. The theme will be related to the education of character development as an independent human figure, tough, hard worker and noble character. The characters are taken from the historical story that developed among the people in the area of West Java.
\end{abstract}




\section{INTRODUCTION}

Technology has become the consumption of the wider community, one of which is the entertainment needs for games such as games. Many games are on the market but the substance is not feasible for children's consumption as well as the figures shown are derived from foreign cultures with themes emerging about violence and sadism. Therefore it is necessary research that produce products in the form of games based on local culture and themed moral education is good, especially children.

Currently not many games are excavated from local culture whether it's cultural background or the hero characters are displayed that relate to the history of Indonesian culture. One example is about the Sunda kingdom, Pakuan Pajajaran, which is very famous story in the area of West Java. But knowledge about the history of Indonesian culture is very minimal owned by the child even they do not know him. They know more familiar figures like Naruto. They do not know the figure of a young man named Kian Santang (better known as Prabu Siliwangi) who have the power can move places in the blink of an eye. He only mentioned where he was going and he was instantly in the place.

Games are generally divided into two parts namely, physical games and electronic games. Physical game is a game that is often played like toy cars, dolls, and others. While electronic gaming is a more modern game that is very interesting and phenomenal at this time. Almost everyone plays this electronic game. Examples of this electronic game itself is Touch online, Point Blank, Audition Ayodance, and more. Games like the example above that has a lot to make, there are even games on the mobile smartphone or commonly called android. These games have a very complex database and perfect so that makes the games very good. The problem is the games that have been made too complex so it is not easily understood by many people, especially children.

The need for entertainment and games in the form of games has become a daily consumption for people's lives, especially among children. But the need for the development of games that are based on local culture to preserve the culture that grows in the community so it does not fade swallowed the times. The solution is to create a 2D game that allows to make it easier for all people to understand, especially children. Research like this also previously been made by Benny Yuniawan Pratama Bima Cakti (2014) with the title Making RPG Game "The Legend of Zapatta" using RPG Maker VX. And Mohamad Khairul Alim (2014) with the title Game 2D "Janoko Adventure" using RPG Maker VX. But all the research game development that has been created has not explored the richness of Indonesian culture. So that required games that can provide entertainment and also at the same time provide knowledge and preserve the history of Indonesian culture. This fact is very important in the formation of character building of the nation (character building) which is expected to form future generations that are independent, tough, strong, hardworking and noble.

There are several types of games that can be classified as follows: 1.Maze Game, 2. Board Game, 3. Card Game, 4. Racing Game, 5. Fighting Game, 6. RPG (Role Playing Game). In addition games can also be developed into several parts such as:

1). Game Concept Design

In this section is determining the basic idea of the game as a whole and the type of game that is developed is Role Playing Game (RPG). And in this section also determined the goals and target games developed such as children, adolescents, or adults.

2). Game Game Implementation

Game engine is the core or main engine of the game that controls all activities and interactions that occur in the game. In the development of this game, used RPG Maker VX as a game engine.

Understanding of local culture that is: a culture that grows and develops and is owned and recognized by local ethnic communities. Local cultures usually grow and flourish in a particular tribal or area society because of the hereditary heritage that is preserved. The culture of this region will arise when the inhabitants of a region have had the same mindset and social life, thus becoming a habit that distinguishes them from the rest of the population. Cultural areas began to look developed in Indonesia in the days of previous kingdoms. It can be seen from the way of life and social interaction of each royal community in Indonesia are different from each other. Each tribe scattered throughout the territory of Indonesia has a different culture between one another. Indonesia is one of the richest local cultures in the world, because Indonesia has 200 to 250 ethnic groups with different cultures. 
Edugames who have become a prototype is taking the story of the history of the Sunda kingdom in West Java is the story of King Siliwangi very well known in the history of Sunda as a King of Pajajaran. One of the ancient manuscripts that describes the journey of Prabu Siliwangi is the book of Suwasit.Book written by using ancient Sundanese inside a white Tiger skin found in the village of Rajagaluh Pajajaran west java. King Siliwangi a great king choose the magic Mandraguna, Arif \& Bijaksana Ruled his People in Pakuan Pajajaran kingdom. He is the son of King Prabu Anggalarang or King god Niskala King of the Elephant kingdom of the Galuh dynasty who ruled in Surawisesa or Kraton Galuh in Ciamis West Java. Initially Prabu Siliwangi embraced Islam but after the death of his beloved wife he re-embraced his ancestral religion Sunda Wiwitan. His son Kian Santang and his grandson Sunan Gunung Jati, Syarif Hidayatullah, tried to invite King siliwangi again embraced Islam. But rejected and finally to avoid bloodshed, with the supernatural powers of King Siliwangi obliterate himself and the kingdom of Pajajaran moved into the unseen and everything turned into a wilderness and believed Prabu Siliwangi transformed into a white tiger..

\section{METHOD}

The process of designing Edugames-based learning media based on local culture for the Child as a whole through several stages of research. These stages include system planning in accordance with user requirements, system analysis, system design, system implementation, and support of the system. Output from system planning generated requirements that suit the needs of users. Here is an explanation of the stages carried out in the research that will be implemented:

\section{Library Studies and Feasibility}

The literature study is a source of knowledge on this research which is carried out through the search of some educational experts (education practitioners and academics) English and literature in various forms of documents. The literature study is an in-depth study of information and communication excavation to be justified by an expert on content of edugames.

\section{Data collection}

Data collection is done by several processes including:

a. Edugames search which includes the instructional materials, models, and learning methods currently in use.

b. Interview with a number of experts and practitioners edugames in the computer lab environment Famipa Computer Science Department at the University of Pakuan Bogor.

c. Conducting a field survey to Bantarjati 8 State Elementary School in North Bogor District with the aim of obtaining a general overview of the preparation, operation and mechanism for using edugames among students aged 7 to 12 years.

The research method applied to the development of "Making Game" Little Kingdom of Padjajaran "using RPG Maker VX Ace" is using Multimedia Development Life Cycle (MDLC) method. The work stages that must be passed is to create a concept and then design, collecting material, assembly, testing and final stage of the distribution.

\section{RESULTS AND DISCUSSIONS}

Every child ages 7 to 12 loves the game, but a lot of games that take up children's free time, are not useful because the game is violent and should not be seen by children. This leads to parental unrest. Many game products that smelled of foreign culture so that children do not know the history and culture of its own nation. This situation is very influential on character education and moral of the children as the successor of this nation.

The low knowledge of the nation's history and culture will cause the quality of Indonesian human beings vulnerable to foreign cultural influences and ignore their own history and culture. This will certainly have the potential to damage the nation and character of the nation that is noble and loaded 
with local wisdom in maintaining the history and culture of the nation to strengthen the unity of the Republic of Indonesia.

Based on this fact, it is necessary to develop learning media loaded with local content both history and Indonesian culture. Learning in the form of games such as edugames is considered appropriate in tackling the issue of moral degradation and the next generation of this nation. The products will be displayed in the form of historic and cultural loading of each tribe in Indonesia, for example the Sundanese tribe by displaying the history of Pakuan Pajajaran with the characters who spread the religion of Islam in tatar Sunda. It is hoped that the nation's successor children will recognize and understand the history and culture of the nation and strengthen its identity so that it is not easy to be influenced by foreign culture.

\section{Storyline and Character Development}

The first step is to create a storyline board and character development of the selected story material. The selection of research objects about the local culture raised is the history of Pakuan-Pajajaran kingdom. Nuance of localization that emerges is the history of the Sunda kingdom with the main character Prabu Siliwangi. Stories in RPGs must be creative, innovative, and flowing along with the development of the main character and supporting figures. Usually the story in RPG contains elements like the following: a. The hero, b. The hero's partner, c. Comrades of the hero, d. The traitor, e. The ultimate enemy is hidden.

2. Stage of concept is to determine the purpose and the user of the program (audience identification), the kinds of applications (presentations, interactive, etc.), application objectives (information, entertainment, training, etc.), and general specifications. Basic rules for design are also specified at this stage, such as app sizes, targets, and more.

a) Executive Summary

The project created is a mini game, which is game advanture. Where to finish a game like this is to complete the mission in each stagenya and level up. The storyline of this game is taken from the story of royal history alignment, then recycled the ceiling and lifted into a game by the author. This game will be based on desktop PC. For the work of this game itself is divided into several workmanship by the author.

b) Detail Concept of the game Little Kingdom of Padjajaran is a 2D PC game. This game wil consist of several parts / stage. Where players must complete each stage in order to achieve the ultimate goal of this game. If it fails in one stage the player will repeat the game from the initial stage.

c) Core Game Play

Little Kingdom game This Padjajaran is a desktop PC game. To play this game the control only needs to be done by using the keyboard.

3. Stage Design is to make a detailed specification of the program architecture, style, appearance and material needs / materials for the program. Specifications are made in detail so that in the next stage, collecting and assembling materials are not required for new decisions, but using what is already specified in the design stage. However, the frequent addition of materials or parts of the application is added, omitted, or modified at the start of project work. This stage usually uses a storyboard to describe the description of each scene, by listing all the multimedia objects and links to other scenes and flowcharts to illustrate the flow from one scene to another.

4. Phase of Material Collecting is done making the main character image to be used in this game, the animation for the movement used by the character later and the sound of narration which will be the effect when NPC deliver the message, and others needed for the next stage.

5. Stage Assembly is the stage where all multimedia objects are created. Application creation based on flowchart view, navigation structure, or object diagram coming from the design stage. From this stage using RPG Maker VX Ace software. 
6. Testing Stage will include structural testing, functional trials, and validation trials. Structural testing is done to determine whether the system has been well structured and correct in accordance with the design that has been made to adjust the interface premises layout design. Functional testing, based on the navigation process and validation contained in the system whether it is running in accordance with the design of the navigation structure and its functions. A validation test is performed to ascertain whether the system logic function is working properly.

7. Distribution Stage. This stage of application will be stored in a storage media. This stage can also be called the evaluation stage for the development of ready-made products to become better. The results of this evaluation can be used as input for the concept stage in the next product.
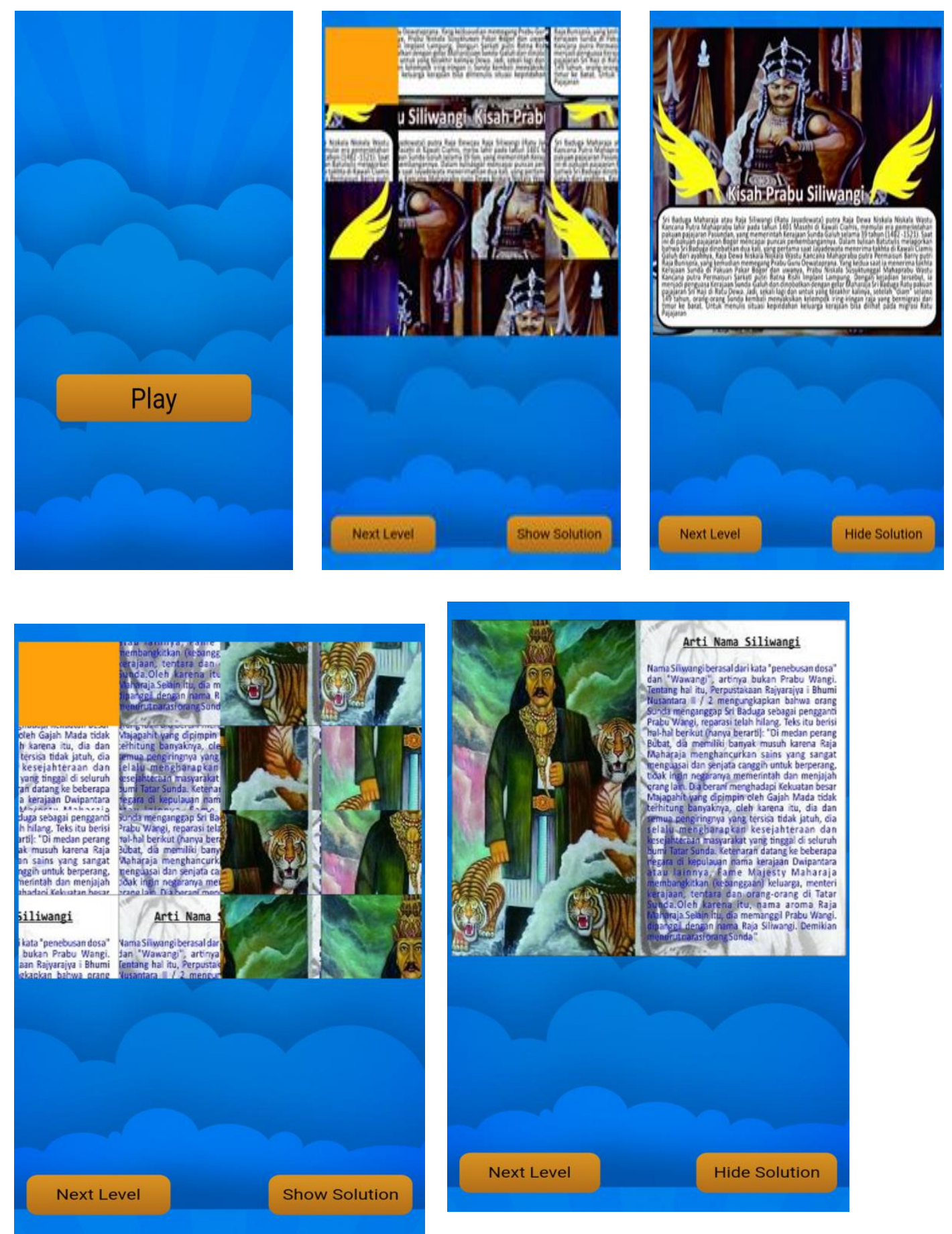

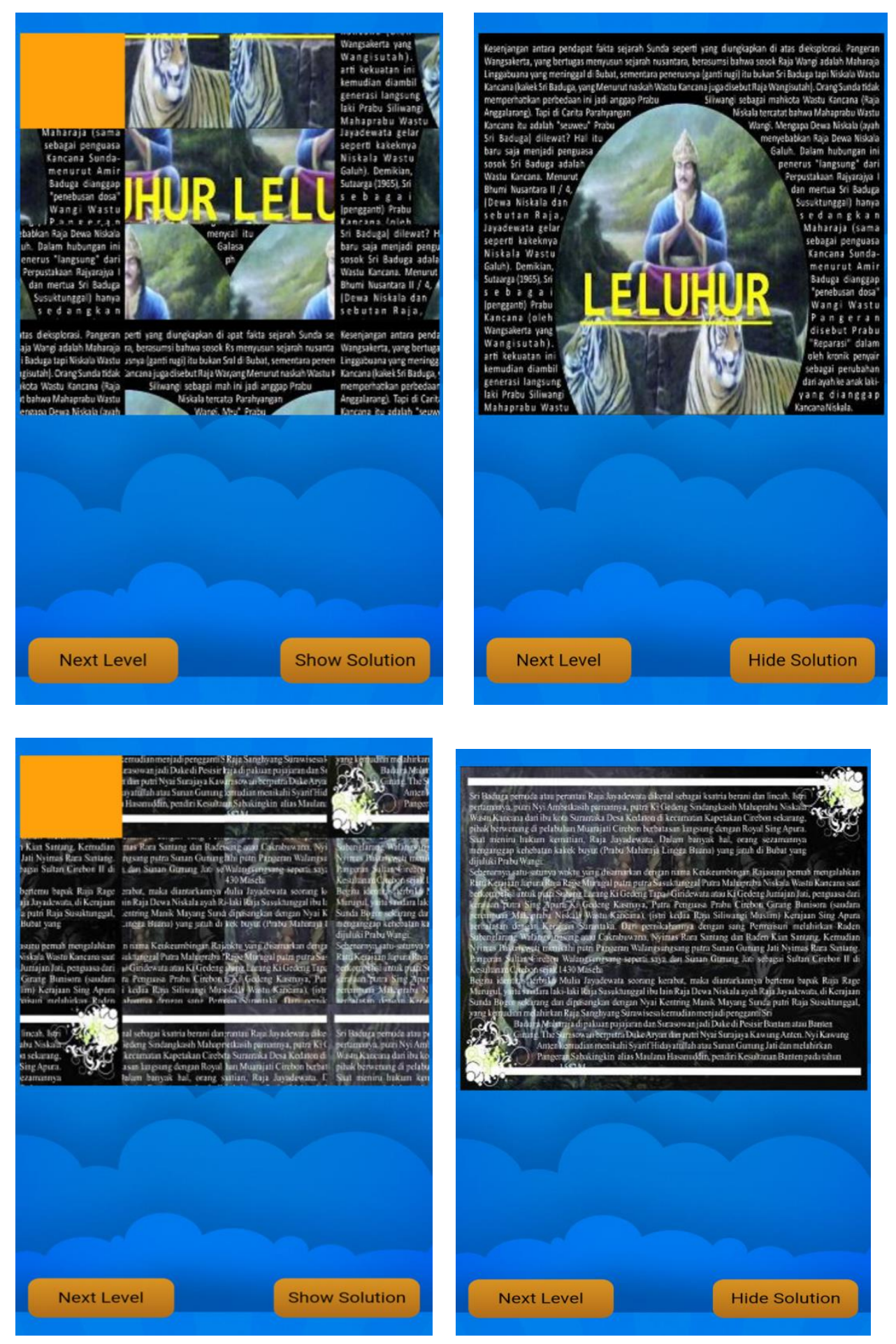

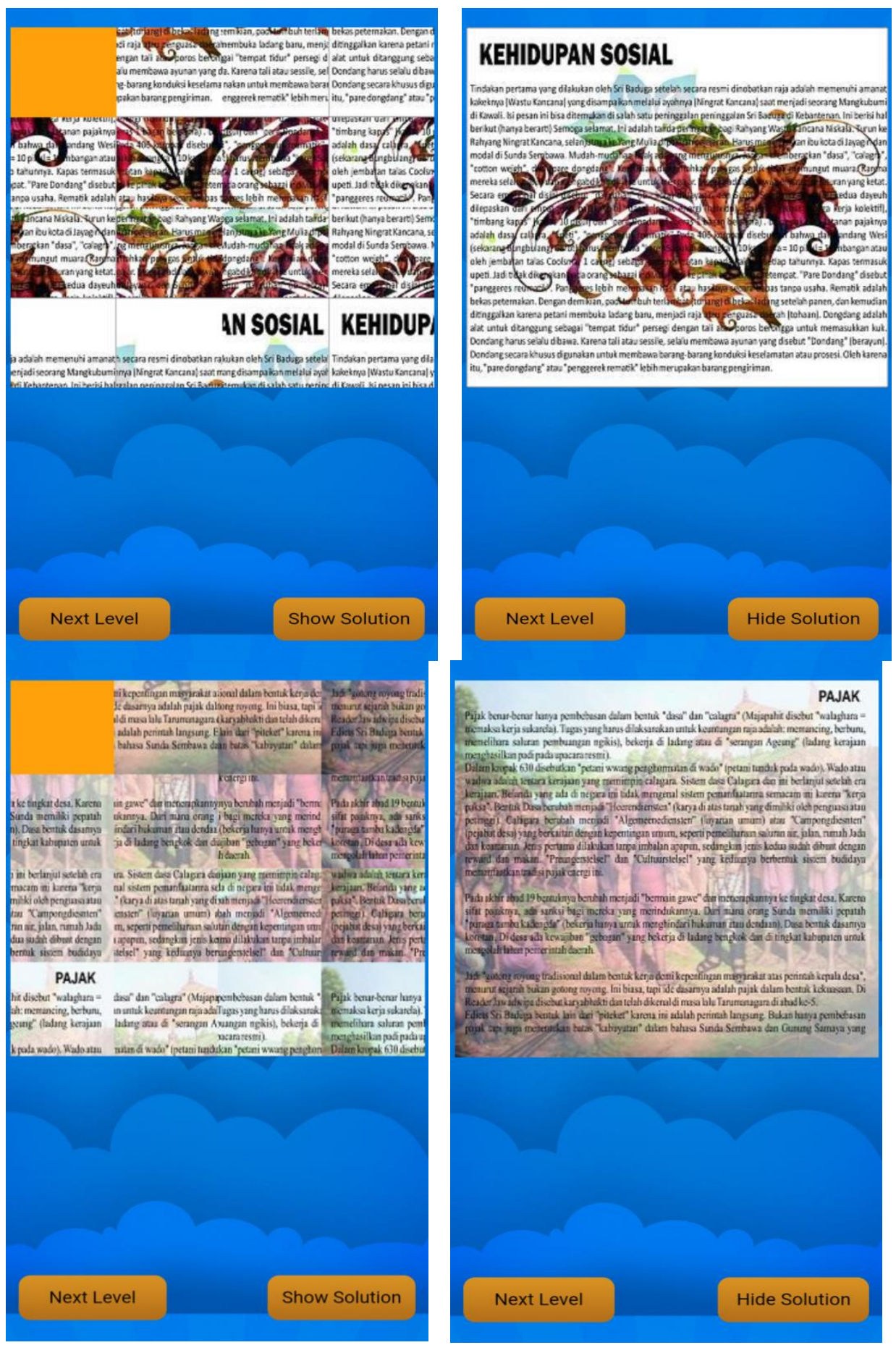

\section{CONCLUSION}

Based on the results of existing research, many games are made as already done by Benny Yuniawan Pratama Bima Cakti (2014) with the title Making RPG Game "The Legend Of Zapata" using RPG Maker VX. Have a goal to create the game of the legend of Zapata is simple and interesting and easy to play, so that later will grow and train the dexterity and thinking power of the player. Mohamad Khairul Alim (2014) titled 2D Game Game "Janoko Adventure" using RPG Maker VX has a goal to be an interesting game and can be played by all ages because it does not contain elements of violence and pornography in it. Arief Syuhada (2014) with the title Designing Game Application Design Build Numbers Using Exact String Methods that have a purpose to apply the Exact String method.

All games are still general. We therefore conducted a study that included elements of local culture in edugames entitled: Little Kingdom of Pajajaran. With the inclusion of local culture is expected the games 
are not solely aimed just to entertain but to be an entertaining edugames as well as there is a learning history of Indonesian Culture in it and strengthen the character building learning about the strong leaders of powerful, hardworking, noble morals. Edugames are still in the form of prototype and will do further research that makes edugames based on local culture in the form of ready-made products and then ready to be disseminated and marketed. Furthermore edugames content can be developed into other local cultural forms that exist in Indonesia.

\section{REFERENCES}

Anggara, (2008). Memahami Teknik Dasar Pembuatan Game Berbasis Flash, Yogyakarta: Gava Media.

Benny Yuniawan Pratama Bima Cakti 2014, Pembuatan Game RPG “The Legend Of Zapata" menggunakan RPG Maker VX.

Gordon C. Everest, 1986. Database Management: Objectives, System Functions, and Administration

\section{http://www.temukanpengertian.com/2015/04/pengertian-budaya-lokal.html}

http://kisahdanbabad.blogspot.co.id/2013/02/perjalanan-sang-prabu-silihwangi.html

H. A. Simon, 1987. Human Computer Interaction Handbook: Fundamentals, Evolving Technologies

Ivan C. Sibero 2009, Langkah Mudah Membuat Game 3D. Elex Media Komputindo

John C Beck \& Mitchell Wade 2013 The Kids are Alright: How the Gamer Generation is Changing the Workplace.

Jasson, 2009. Role Playing Game (RPG) Maker. CV ANDI OFFSET, Yogyakarta, Hal 2

Mohamad Khairul Alim 2014, Pembuatan Game 2D "Petualangan Janoko" menggunakan RPG Maker VX.

Mei , Yin Yong \& Yu-jing, J., (2000). From using games in an EFL class for children. Daejin $\begin{array}{lllll}\text { University ELT Research } & \text { Paper. }\end{array}$ http://english.daejin.ac.kr/ rtyson/fall2000/elt/games.html retrieved 20 February 2010 retrieved 20 February 2010.

Nandi, 2006. Penggunaan Multimedia Interaktif Dalam Pembelajaran Di Persekolahan. Jurnal "GEA" Jurusan Pendidikan Geogarafi Vol.6, No.1, April 2006.

Shneiderman's "Eight Golden Rules of Interface Design", University of Washington Online. Home page on-line. Available from Http://faculty.washington.edu/jtenenbg/courses/360/f04/sessions/schneidermanGoldenRules. html; Internet; accessed 13 April 2016.

Suheri, Agus. 2006. Animasi Multimedia Pembelajaran. Jurnal Informatika Volume 2-No.1 : Periode Juli Desember 2006

Sutopo, Hadi, A., 2003, Multimedia Interaktif dengan Flash. Graha Ilmu, Yogyakarta.

Suyanto, Muhammad. 2004. Analisis \& Desain Aplikasi Multimedia untuk Pemasaran. Yogyakarta: Andi. 